\title{
Soil Respiration and Organic Carbon Dynamics with Grassland Conversions to Woodlands in Temperate China
}

\author{
Wei Wang $^{1 *}$, Wenjing Zeng ${ }^{1,2}$, Weile Chen ${ }^{1,2}$, Hui Zeng ${ }^{2}$, Jingyun Fang ${ }^{1}$ \\ 1 Department of Ecology, College of Urban and Environmental Sciences, and Key Laboratory for Earth Surface Processes of the Ministry of Education, Peking University, \\ Beijing, China, 2 Key Laboratory for Urban Habitat Environmental Science and Technology, Peking University Shenzhen Graduate School Shenzhen, China
}

\begin{abstract}
Soils are the largest terrestrial carbon store and soil respiration is the second-largest flux in ecosystem carbon cycling. Across China's temperate region, climatic changes and human activities have frequently caused the transformation of grasslands to woodlands. However, the effect of this transition on soil respiration and soil organic carbon (SOC) dynamics remains uncertain in this area. In this study, we measured in situ soil respiration and SOC storage over a two-year period (Jan. 2007Dec. 2008) from five characteristic vegetation types in a forest-steppe ecotone of temperate China, including grassland (GR), shrubland (SH), as well as in evergreen coniferous (EC), deciduous coniferous (DC) and deciduous broadleaved forest (DB), to evaluate the changes of soil respiration and SOC storage with grassland conversions to diverse types of woodlands. Annual soil respiration increased by $3 \%, 6 \%, 14 \%$, and $22 \%$ after the conversion from GR to EC, SH, DC, and DB, respectively. The variation in soil respiration among different vegetation types could be well explained by SOC and soil total nitrogen content. Despite higher soil respiration in woodlands, SOC storage and residence time increased in the upper $20 \mathrm{~cm}$ of soil. Our results suggest that the differences in soil environmental conditions, especially soil substrate availability, influenced the level of annual soil respiration produced by different vegetation types. Moreover, shifts from grassland to woody plant dominance resulted in increased SOC storage. Given the widespread increase in woody plant abundance caused by climate change and large-scale afforestation programs, the soils are expected to accumulate and store increased amounts of organic carbon in temperate areas of China.
\end{abstract}

Citation: Wang W, Zeng W, Chen W, Zeng H, Fang J (2013) Soil Respiration and Organic Carbon Dynamics with Grassland Conversions to Woodlands in Temperate China. PLoS ONE 8(8): e71986. doi:10.1371/journal.pone.0071986

Editor: Han Y.H. Chen, Lakehead University, Canada

Received March 22, 2013; Accepted July 6, 2013; Published August 23, 2013

Copyright: (c) 2013 Wang et al. This is an open-access article distributed under the terms of the Creative Commons Attribution License, which permits unrestricted use, distribution, and reproduction in any medium, provided the original author and source are credited.

Funding: This research was supported by the National Basic Research Program of China (No. 2012CB956303 and 2010CB950600), projects of the National Natural Science Foundation of China (31222011, 31270363 and 31070428), and projects supported by the Foundation for Innovative Research Groups of the National Natural Science Foundation of China (No. 31021001). The funders had no role in study design, data collection and analysis, decision to publish, or preparation of the manuscript.

Competing Interests: The authors have declared that no competing interests exist.

*E-mail: wangw@urban.pku.edu.cn

\section{Introduction}

Soils are the largest store of carbon in the biosphere [1], so small changes in soil organic carbon (SOC) storage will profoundly influence atmospheric $\mathrm{CO}_{2}$ concentrations and potentially influence the global climate [2]. Moreover, soil respiration is the second largest flux of carbon between terrestrial ecosystems and the atmosphere [3]. Global changes have substantially impacted soil respiration and, in turn, SOC dynamics $[4,5]$. However, soils are the largest source of uncertainty in the terrestrial carbon balance [6].

Natural and anthropogenic-induced vegetation-type conversions are among the most important components of global changes [7]. The shifts between grasslands and plant communities dominated by woody vegetation are one of the most frequent occurring vegetation transition types $[8,9,10,11,12]$. For instance, deforestation is believed to be a major anthropogenic source of $\mathrm{CO}_{2}$ to the atmosphere $[13,14,15,16,17]$. In contrast, large scale forest expansion and re-growth may be important sources for the missing carbon sink $[18,19]$. Vegetation-type conversions influence the balance of organic carbon in soil and hence may cause changes in soil respiration [20,21]. Changes in vegetation-type are expected to have major effects on the terrestrial carbon balance [22].

Shifts in vegetation types may profoundly affect the dynamics of soil respiration and SOC by influencing soil microclimate and the production and transfer of aboveground photosynthate to belowground [23,24,25,26,27]. However, the direction of changes in the soil respiration and the consequent changes in organic carbon storage in soil within adjacent grass-woody vegetative transition is still controversial $[28,29,30]$. The inconsistencies may, to a large degree, be caused by the differences in the various locations and the types of transition occurring [31].

Because regional aspects of the global carbon cycle are drawing increasing scientific and political interest, there is a strong impetus to better understand how land use change effects China's carbon balance $[32,33,34]$. However, few reports on soil respiration and SOC dynamics are available. Furthermore, the currently available studies were mainly conducted in China's southern tropical and sub-tropical areas $[35,36,37,38,39,40]$. Nevertheless, the temperate areas of northern China are also experiencing frequent, diverse and continuous transitions in the vegetation types, which should 
substantially affect SOC dynamics and soil respiration in this area. Since the 1970s, the Chinese government has implemented several ecological restoration projects, including the Three-North Shelterbelt Program covering $41 \%$ area of the country, across the temperate regions of China that receive less than $400 \mathrm{~mm}$ of precipitation annually. These reforestation and afforestation activities were believed to influence carbon cycling and carbon storage in this area $[41,42]$. In addition, the study of dynamics of organic carbon in soil shows the level of organic carbon in soil is relatively sensitive to increasing temperatures in the temperate climatic zone [43]. Therefore, evaluating how large-scale transitions of vegetation types influence soil respiration and consequent SOC storage is critical to calculating temperate China's carbon budget under the scenario of global change.

In this study, we quantify soil respiration and SOC dynamics from five adjacent grass-woody vegetation types in the temperate areas of northern China. We aimed to 1) measure annual soil respiration as well as SOC storage and residence time, and 2) explore the major drivers for the variations in soil respiration among different vegetation types. We hypothesized that 1) soil respiration as well as SOC storage and residence time were higher in woody vegetation types than in grasslands, and 2) vegetationmediated change in soil microenvironments was a major driver for the variation of soil respiration.

\section{Materials and Methods}

\section{Ethics Statement}

The administration of the Saihanba Forestry Center gave permission for this research at each study site. We confirm that the field studies did not involve endangered or protected species.

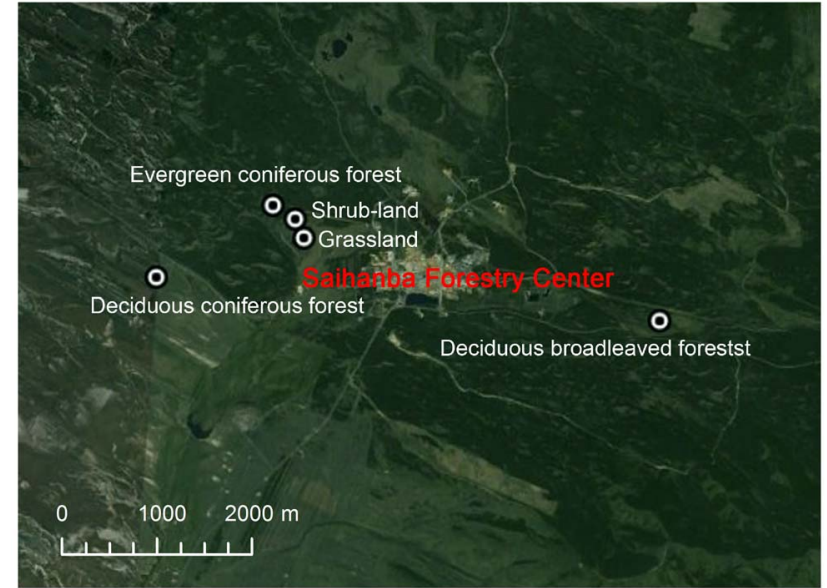

Figure 2. The location of five vegetation types in Saihanba Forestry Center.

doi:10.1371/journal.pone.0071986.g002

\section{Site description and land-use history}

The study was conducted at the Saihanba Forestry Center in Hebei Province and Inner Mongolia Autonomous Area, northern China $\left(117^{\circ} 12^{\prime}-117^{\circ} 30^{\prime} \mathrm{E}, 42^{\circ} 10^{\prime}-42^{\circ} 50^{\prime} \mathrm{N}, 1,400 \mathrm{~m}\right.$ a.s.l.). The study area has a semi-arid and semi-humid temperate climate and lies in a typical forest-steppe ecotone on predominately sandy soils with long and cold winters (November to March), and short springs and summers. Annual mean air temperature and precipitation from 1964 to 2004 were $-1.4^{\circ} \mathrm{C}$ and $450.1 \mathrm{~mm}$, respectively.

This area contains the largest of plantation forests in China, with evergreen Pinus sylvestris L. var. mongolica Litv. (Mongolia pine) and deciduous Larix principis-rupprechtii Mayr (larch) as dominant

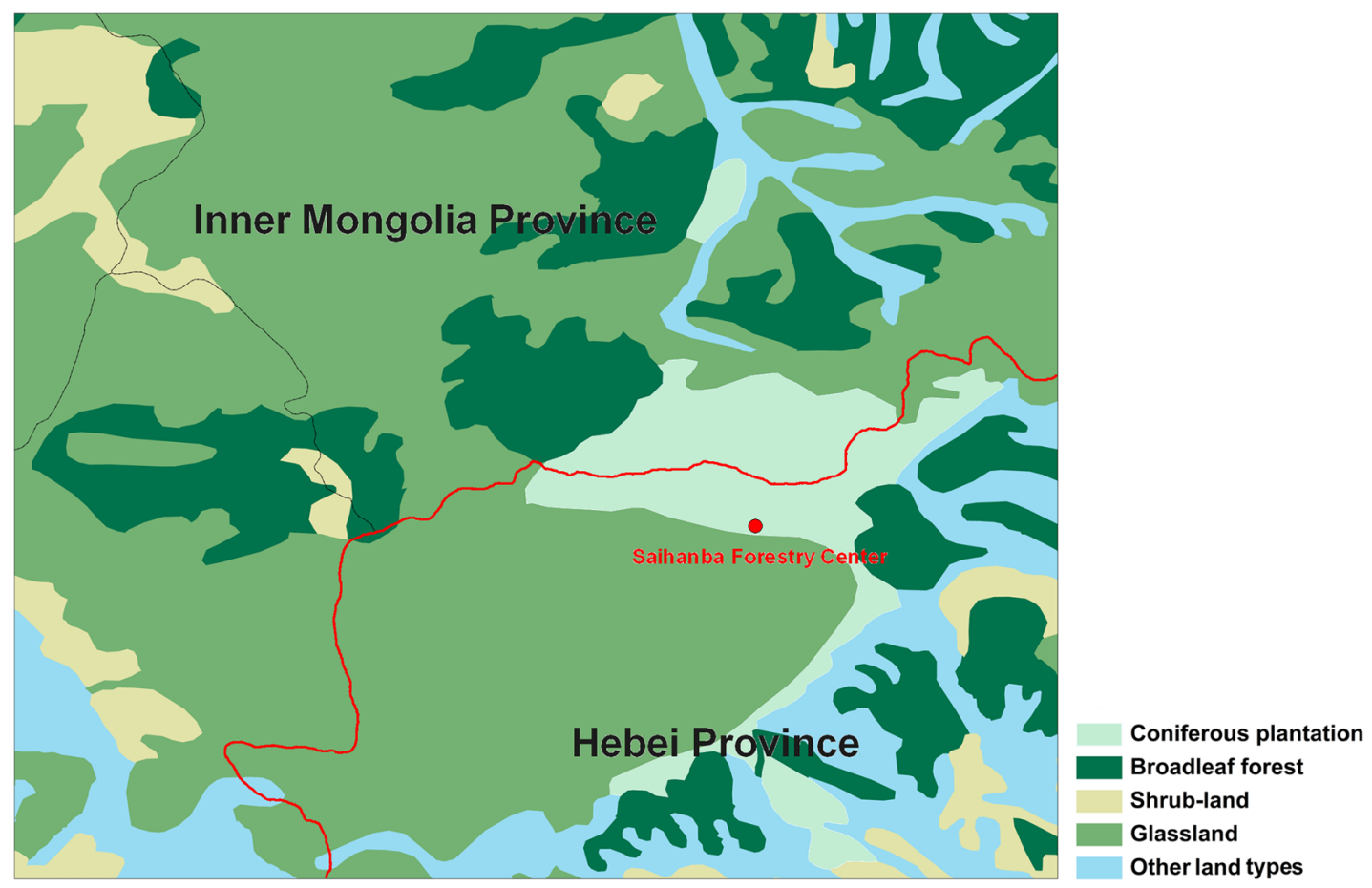

Figure 1. Current land-use patterns at the study site. From a 1:1,000,000 scale map of the vegetation types of China [72]. doi:10.1371/journal.pone.0071986.g001 
Table 1. Site characteristics and physical and chemical properties of topsoil $(0-20 \mathrm{~cm})$.

\begin{tabular}{|c|c|c|c|c|c|c|c|c|c|}
\hline Site & $\begin{array}{l}\text { Vegetation } \\
\text { types }\end{array}$ & $\begin{array}{l}\text { Domain } \\
\text { species }\end{array}$ & NDVI & ST $\left({ }^{\circ} \mathrm{C}\right)$ & SWC (\%) & $\begin{array}{l}\text { SOC } \\
\left(g^{-2}\right)^{-2}\end{array}$ & $\begin{array}{l}\text { STN } \\
\left(g_{~ m^{-2}}\right)\end{array}$ & $\begin{array}{l}\text { Soil } \\
\text { pH }\end{array}$ & $\begin{array}{l}\text { SBD }^{*} \\
\left(\mathrm{~g} \mathrm{~cm}^{-3}\right)\end{array}$ \\
\hline GR & grassland & Leymus chinensis & $0.44^{\mathrm{a}}$ & $3.8^{\mathrm{a}}$ & $8.4^{\mathrm{a}}$ & $1476.7^{\mathrm{a}}$ & $136.5^{\mathrm{a}}$ & $6.28^{a}$ & $0.92^{\mathrm{a}}$ \\
\hline $\mathrm{SH}$ & shrubland & $\begin{array}{l}\text { Rosa bella Rehd. et Wils } \\
\text { \& Malus baccata* }\end{array}$ & $0.38^{\mathrm{b}}$ & $3.4^{\mathrm{a}}$ & $12.6^{\mathrm{b}}$ & $1841.5^{\mathrm{a}}$ & $189.4^{b}$ & $6.30^{\mathrm{a}}$ & $0.71^{b}$ \\
\hline EC & $\begin{array}{l}\sim 15 \text { yr old evergreen } \\
\text { coniferous plantation }\end{array}$ & $\begin{array}{l}\text { Pinus sylvestris } \\
\text { var. mongolica }\end{array}$ & $0.55^{\mathrm{c}}$ & $3.2^{\mathrm{a}}$ & $7.3^{\mathrm{a}}$ & $2022.7^{\mathrm{a}}$ & $146.2^{\mathrm{a}}$ & $6.45^{\mathrm{a}}$ & $0.98^{\mathrm{a}}$ \\
\hline DC & $\begin{array}{l}\sim 15 \text { yr old deciduous } \\
\text { coniferous plantation }\end{array}$ & $\begin{array}{l}\text { Larix principis- } \\
\text { rupprechtii }\end{array}$ & $0.36^{\mathrm{b}}$ & $3.6^{\mathrm{a}}$ & $7.8^{\mathrm{a}}$ & $2993.9^{b}$ & $172.8^{\mathrm{a}}$ & $6.30^{\mathrm{a}}$ & $1.06^{\mathrm{a}}$ \\
\hline DB & $\begin{array}{l}\sim 45 \text { yr old deciduous } \\
\text { broadleaved forest }\end{array}$ & $\begin{array}{l}\text { Betula } \\
\text { platyphylla }\end{array}$ & $0.51^{d}$ & $1.7^{\mathrm{b}}$ & $19.7^{c}$ & $2830.7^{b}$ & $287.7^{c}$ & $5.92^{b}$ & $0.69^{\mathrm{b}}$ \\
\hline
\end{tabular}

*SH contained two different dominant species in separate plots and the results of those plots were averaged in our study.

$\mathrm{NDVI}=$ Normalized Difference Vegetation Index, soil temperature $=\mathrm{ST}$, SWC $=$ soil water content, SOC = soil organic carbon, STN $=$ soil total nitrogen, SBD = soil bulk density. Different lowercase letters indicated significant differences $(P<0.05)$.

doi:10.1371/journal.pone.0071986.t001

species; secondary deciduous forests mainly consist of Betula platyphylla Sukaczev (birch). In addition, shrublands dominated by Rosa bella Rehd. et Wils. (Solitary rose) and Malus baccata (L.) Borkh. (Siberian crabapple) and meadow grasslands are also very common (Fig. 1). The herbaceous layers of Mongolia pine and larch are similar, and are composed of Sanguisorba officinalis L. (Radix Sanguisorbae), Thalictrum aquilegifolium L., Agrimonia pilosa Ledeb. and Carex stenophylla Wahlenb., while the herbaceous layer of birch is made up of Agrimonia pilosa Ledeb. and Radix Sanguisorbae. The herbaceous layer of Siberian crabapple is dominated by Veronica linarïfolia Pall. ex Link, Galium verum L., Heteropappus hispidus (Thunb.) Less., Trollius chinensis Bunge, and Bupleurum chinense DC. The herbaceous layer of Solitary rose

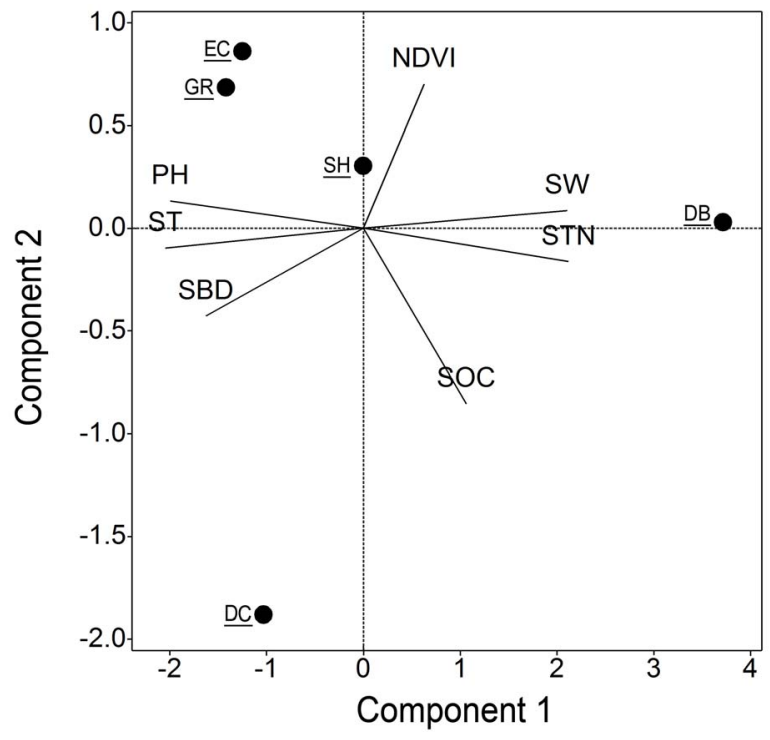

Figure 3. Principal component analysis of site properties. Score plot of five vegetation types during Principal Component Analysis of site properties, including normalized difference vegetation index $(\mathrm{NDVI})$, soil temperature (ST), soil water content (SWC), soil organic carbon (SOC), soil total nitrogen (STN), soil $\mathrm{pH}$, and soil bulk density (SBD). Habitats were grassland (GR), shrubland (SH), evergreen coniferous forest (EC), deciduous coniferous forest (DC), and deciduous broadleaved forest (DB).Seasonal dynamics of soil respiration doi:10.1371/journal.pone.0071986.g003 consists of Leymus chinensis (Trin.) Tzvelev. The meadow grassland is zonal vegetation dominated by $L$. chinensis.

The current land-cover pattern resulted from both natural and human-induced vegetation type transitions: from $\sim 5900$ to $\sim 2900$ ${ }^{14} \mathrm{C}$ years $\mathrm{BP}$, the original deciduous broadleaf forest (DB) were gradually replaced by evergreen coniferous forest (EC) and deciduous coniferous forest (DC) in those places when climate changed from humid to arid; after $\sim 2900{ }^{14} \mathrm{C}$ years BP, EC and DC shifted to grassland (GR) in some drier places [44]. In the late $1900 \mathrm{~s}$, the remaining primary forests were harvested by large scale industrial logging and initially became grasslands, but more recently the grasslands have been replaced by secondary $\mathrm{SH}, \mathrm{DB}$ and plantations of EC and DC. Furthermore, based on the trends for increasing temperature and precipitation in this area [45], together with the large-scale reforestation and afforestation policy of the Chinese government [42], the cover area of woody vegetation types is predicted to increase in the future.

\section{Experimental plot design}

The abundant vegetation types co-occurring in our study area provide an excellent opportunity to examine how ecological processes respond to changes in vegetation type. We selected five adjacent grass-woody vegetation types (Fig. 2) to study the influences of vegetation type transitions on biogeochemical processes. All sites for these vegetation types were less than $5 \mathrm{~km}$ apart to ensure each site had the same climatic and edaphic condition. Table 1 summarizes the characteristics and species composition of each vegetation type. Three replicates were designed for each of five vegetation types including: GR $(L$. chinensis), SH (R. bella \& M. baccata), EC ( $\sim 15$ year old P. sylvestris var. mongolica), DC ( 15 year old $L$. principis-rupprechtii), and DB

Table 2. The proportion of variation explained from principal component analysis on the seven environmental variables.

\begin{tabular}{llll}
\hline Component & Eigenvalue & Proportion & Cumulative \\
\hline 1 & 4.61 & 0.66 & 0.66 \\
2 & 1.21 & 0.17 & 0.83 \\
3 & 1.01 & 0.15 & 0.98 \\
4 & 0.16 & 0.02 & 1.00 \\
\hline doi:10.1371/journal.pone.0071986.t002 & &
\end{tabular}


Table 3. The loading scores of traits on each component from principal component analysis on the seven environmental variables.

\begin{tabular}{llll}
\hline & & & \\
\hline Variable & Component $\mathbf{1}$ & Component 2 & Component 3 \\
\hline NDVI & 0.14 & 0.58 & -0.71 \\
ST & -0.44 & -0.08 & 0.28 \\
SWC & 0.46 & 0.07 & 0.18 \\
SOC & 0.23 & -0.71 & -0.37 \\
STN & 0.46 & -0.14 & 0.02 \\
pH & -0.43 & 0.11 & -0.10 \\
SBD & -0.35 & -0.35 & -0.49 \\
\hline
\end{tabular}

$\mathrm{NDVI}=$ normalized difference vegetation index, $\mathrm{ST}=$ soil temperature, SWC = soil water content, $\mathrm{SOC}=$ soil organic carbon, $\mathrm{STN}=$ soil total nitrogen, $\mathrm{pH}=$ soil $\mathrm{pH}, \mathrm{SBD}=$ soil bulk density.

doi:10.1371/journal.pone.0071986.t003

( $\sim 45$ year old $B$. platyphylla). Each $20 \mathrm{~m} \times 20 \mathrm{~m}$ plot was sampled with five subsamples (i.e. soil respiration measurement collars).

\section{Soil respiration, soil temperature and moisture}

Soil respiration (SR) was measured using a Li-8100 soil $\mathrm{CO}_{2}$ flux system (LI-COR Inc. Lincoln, NE, USA) from Jan 2007 to Dec 2008. During the growing season (April to October), five polyvinyl chloride (PVG) collars $(10 \mathrm{~cm}$ inside diameter, $6 \mathrm{~cm}$ height above the soil surface) were inserted $3 \mathrm{~cm}$ into the soil in each plot and were left in the same locations throughout the study period. These five PVC collars were placed in each plot, one in the center and one in each corner. Living plants inside the collars were clipped at the soil surface 1 day before each measurement to exclude the effect of aboveground vegetation. SR was measured every 10-15 days. Measurements were made between 08:00 and 11:00 am (based on our measurements of diurnal changes in SR, data not shown) to minimize the daily variation in SR and obtain mean daily SR. For each measurement, respiration rates were calculated as means of three plots for each stand. During winter (November to March), longer soil collars (determined by snow depth, less than $30 \mathrm{~cm}$ ) were inserted into the soil surface and stabilized for $24 \mathrm{~h}$ before measurement of the winter SR [46,47]. The Li-8100 soil $\mathrm{CO}_{2}$ flux system was kept in an isolated and heated container to keep its temperature above freezing point.

Soil temperature (ST) was recorded during respiration measurements near each collar at $5 \mathrm{~cm}$ soil depth with the LI-COR 8100 temperature probe. Continuous measurements of ST at $5 \mathrm{~cm}$ depth were recorded at 30-min intervals with StowAway loggers (Onset Comp. Corp., Bourne, MA, USA) inserted in the soil near one collar at each study site. Soil volumetric water content (SWC) at a depth of $0-10 \mathrm{~cm}$ was measured using time domain reflectometry (Soil Moisture Equipment Corp., Santa Barbara, CA, USA). SWC was only obtained during the growing season because the probe could not be fully inserted into the frozen soil in winter.

\section{Soil sampling and measurements}

Because the carbon stored in topsoil is the carbon pool that is most sensitive to land management practices $[48,49]$, we sampled mineral soils at depths of $0-10$ and $10-20 \mathrm{~cm}$ from five random locations per plot using 5.8-cm diameter soil cores during the summers of 2007 and 2008. Soil bulk density (SBD) of the two soil horizons was quantified in all soil surveys from the mass of the oven-dry soil $\left(105^{\circ} \mathrm{C}\right)$ divided by the volume of the soil cores. Next, all plant materials were removed from fresh soil samples, and soil was passed through a 2-mm sieve. In situ root biomass per unit area was determined by the entire root biomass in the soil core divided by the cross section area of the core. Soil $\mathrm{pH}$ was determined from air-dried soil samples in distilled $\mathrm{H}_{2} \mathrm{O}$ solution, with a $\mathrm{pH}$ meter (Model PHS-2, INESA Instrument, Shanghai, China). The SOC content and soil total nitrogen (STN) were determined from ovendried soil samples with an elemental analyzer (Vario EL III Universal CHNOS Elemental Analyzer, Elementar, Hanau, Germany). The mass-based SOC and STN were converted into area-based with soil bulk density of each horizon (0-10 and 10$20 \mathrm{~cm}$ depth).

NDVI (Normalized Difference Vegetation Index) data

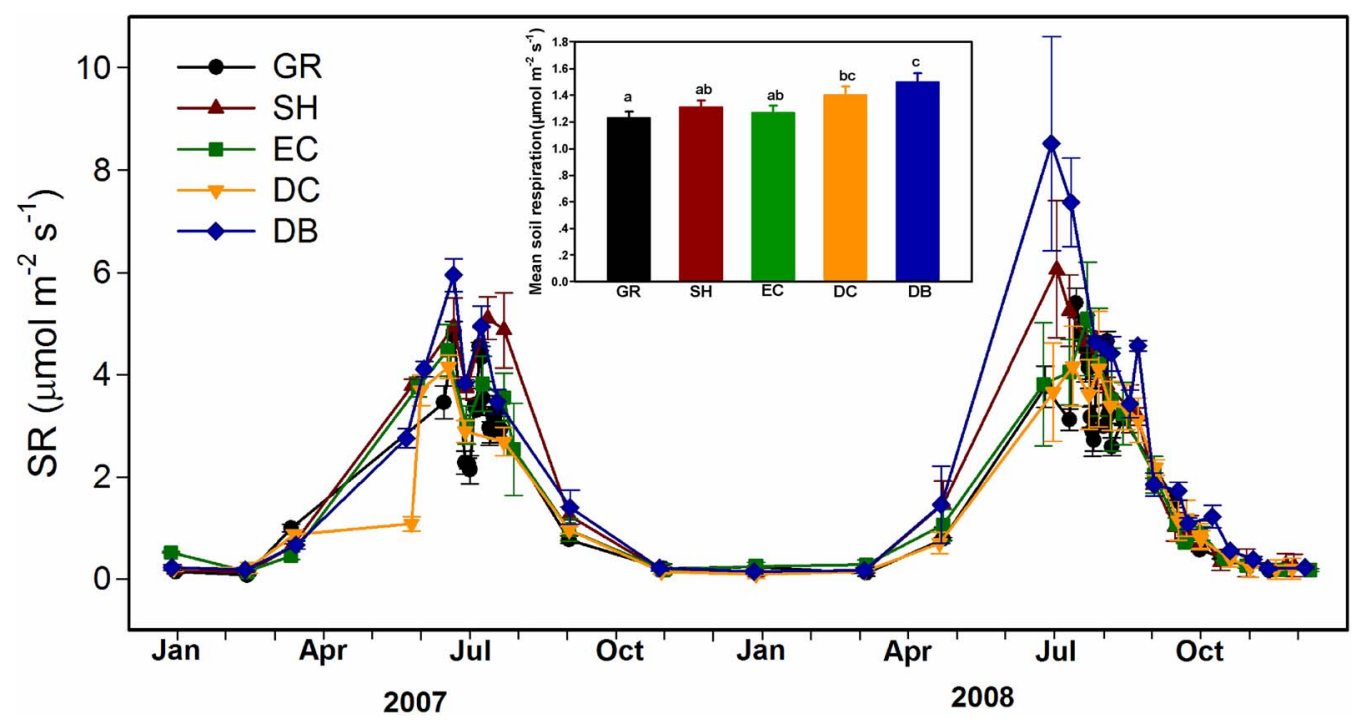

Figure 4. Seasonal dynamics of soil respiration (SR) among five adjacent vegetation types. Habitats are as listed in Fig. 2. doi:10.1371/journal.pone.0071986.g004 


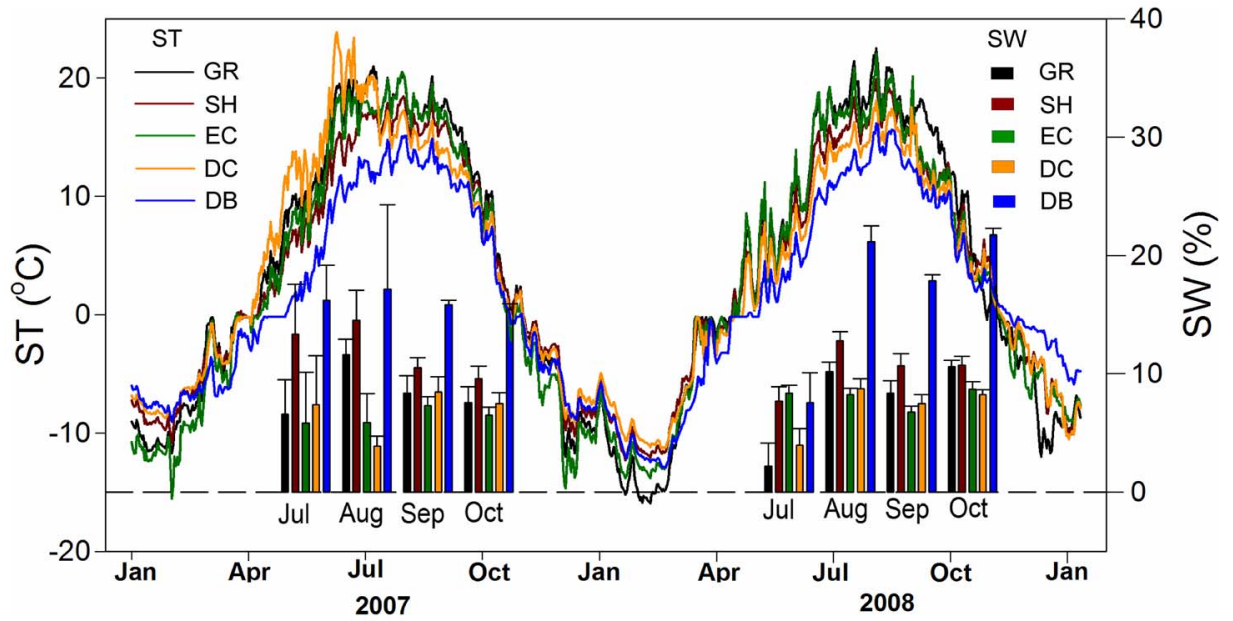

Figure 5. Seasonal dynamics of soil temperature and soil water content across five adjacent vegetation types. ST = soil temperature at $5 \mathrm{~cm}$ depth, SWC $=$ soil water content at $10 \mathrm{~cm}$ depth. Habitats are as listed in Fig. 2.

doi:10.1371/journal.pone.0071986.g005
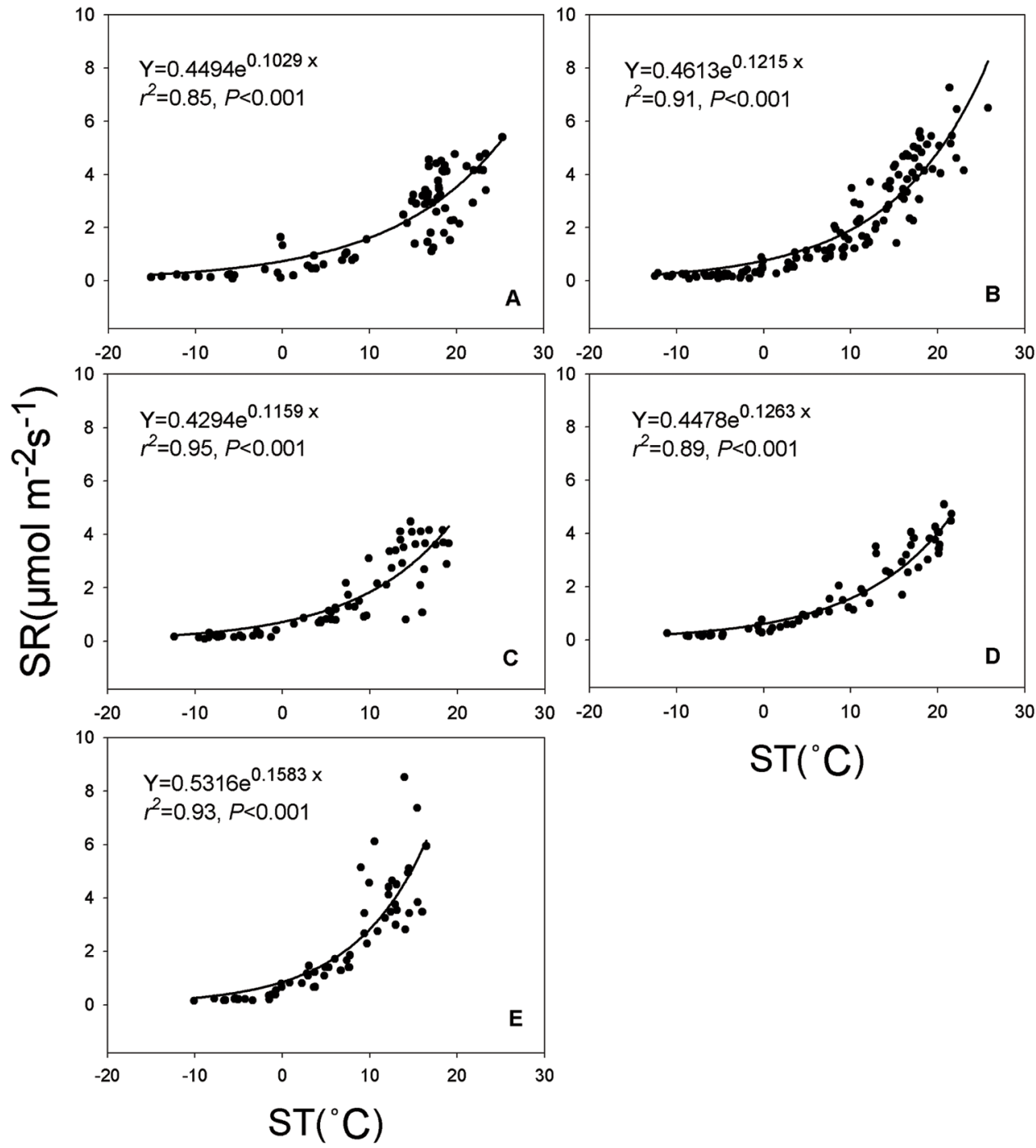

$\mathrm{ST}\left({ }^{\circ} \mathrm{C}\right)$

Figure 6. Relationships between the seasonal dynamics of soil respiration and soil temperature at $\mathbf{5} \mathrm{cm}$ depth across habitats as listed in Fig. 2.

doi:10.1371/journal.pone.0071986.g006 

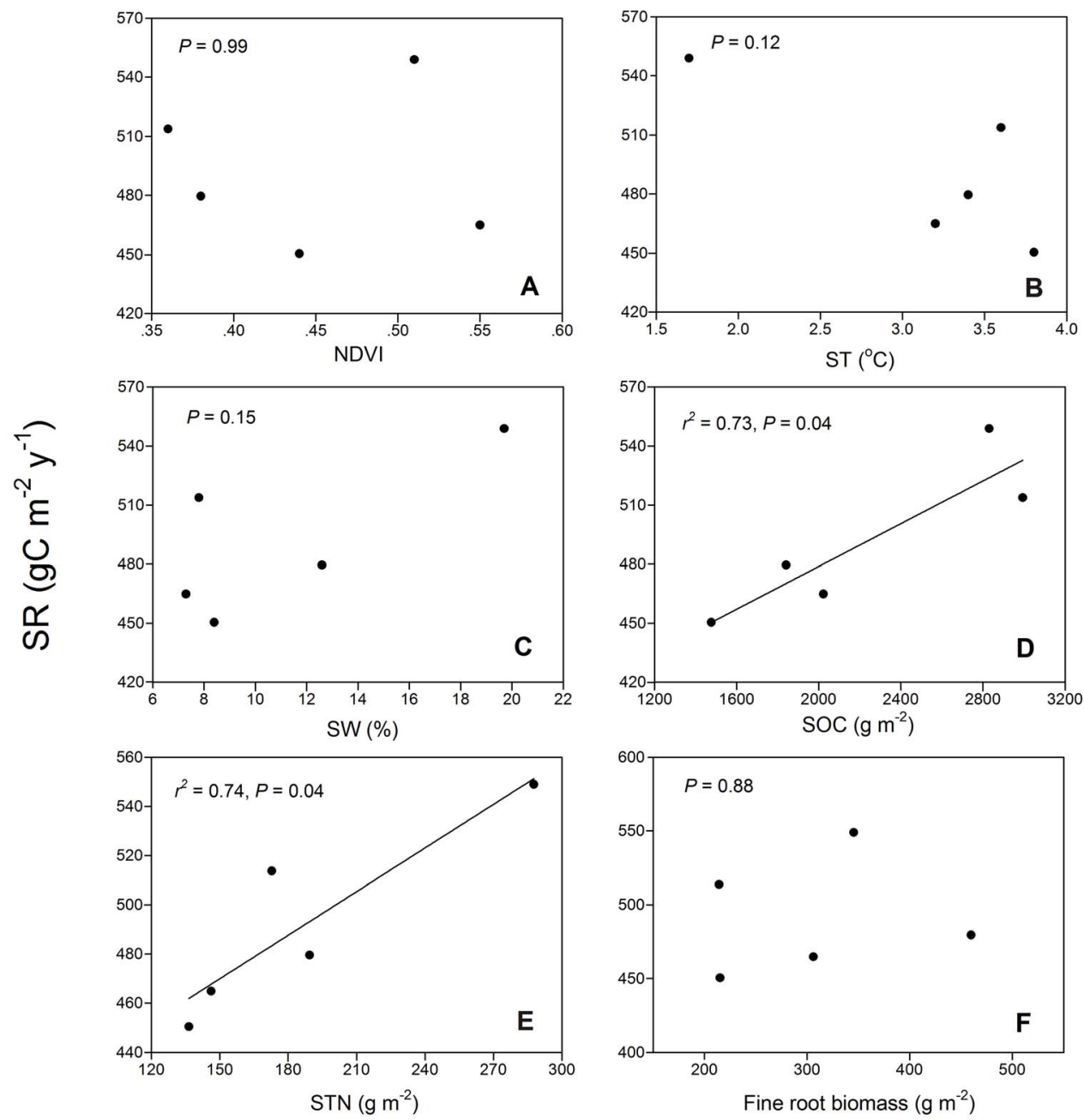

Figure 7. Relationships between annual soil respiration and NDVI (A), soil temperature at $5 \mathrm{~cm}$ depth (ST) (B), soil water content at $10 \mathrm{~cm}$ depth (SWC) (C), soil organic carbon (SOC) (D), soil total nitrogen (STN) (E) from the top $20 \mathrm{~cm}$ depth and fine root biomass at $\mathbf{0}-\mathbf{3 0} \mathbf{c m}$ depth $(\mathrm{F})$ across the five adjacent vegetation types. doi:10.1371/journal.pone.0071986.g007

NDVI is derived from the red: near-infrared reflectance ratio:

$$
N D V I=\frac{(N I R-V I S)}{(N I R+V I S)},
$$

where NIR and VIS stand for the spectral reflectance measurements acquired in the near-infrared and visible (red) regions of the spectrum, respectively [50]. The NDVI depends on photosynthesis and is closely correlated to GPP $[51,52]$. We calculated the mean annual NDVI of each vegetation type from 2007-2008 to analyze the influence of aboveground carbon input on SR. Because the five vegetation types studied here covered large areas and had uniform distributions and sparse understories, NDVI of 16-Day L3Global $250 \mathrm{~m}$ product (MOD13 Q1) could well represent our plot measurements. We downloaded satellite data from our study period from https://wist.echo.nasa.gov/api. Harmonic (Fourier) analysis was used to remove the considerable noise remaining in the NDVI time series from satellite data to obtain reasonably smooth continuous data [53].

\section{Statistical analysis}

We examined the relationships between SR and ST by fitting exponential functions to the data from each vegetation type using the following equation:

$$
S R=a \times e^{\beta \times S T},
$$

where SR is observed soil respiration (plot-wide averages measured periodically throughout the year), ST is the concurrently measured soil temperature $(5 \mathrm{~cm}$ depth), with a and $\beta$ being the fitted parameters obtained using least squares nonlinear regression with SigmaPlot V. 8.02.

Annual SR was estimated with the yearly period continuously measured ST and the exponential function between SR and ST for each vegetation type. The mean residence time of SOC was estimated for each vegetation type by dividing the mass of SOC in the top $20 \mathrm{~cm}$ of the soil profile by the heterotrophic respiration flux, which equals the total SR minus root respiration. Root respiration of each vegetation type was obtained based on the estimates from Wang et al. [54], who measured excised root respiration for all the five vegetation types we studied at the same sites during the same period. 
Table 4. Annual soil respiration, contribution of root respiration to total soil respiration, and soil organic carbon residence time in the top $20 \mathrm{~cm}$ of soil.

\begin{tabular}{|c|c|c|c|c|c|}
\hline Site & $S R\left(g \subset m^{-2} y r^{-1}\right)$ & $\begin{array}{l}\text { Root respiration } \\
\text { contribution* }(\%)\end{array}$ & $H R\left(g \subset m^{-2} y r^{-1}\right)$ & $\operatorname{SOC}\left(\mathrm{g} \mathrm{m}^{-2}\right)$ & $\begin{array}{l}\text { Residence } \\
\text { time (yr) }\end{array}$ \\
\hline$\overline{G R}$ & $450.4^{a}$ & 4.7 & 429.0 & $1476.7^{\mathrm{a}}$ & 3.4 \\
\hline $\mathrm{SH}$ & $479.5^{b}$ & 23.5 & 366.8 & $1841.5^{\mathrm{a}}$ & 5.0 \\
\hline EC & $464.8^{c}$ & 18.3 & 380.0 & $2022.7^{\mathrm{a}}$ & 5.3 \\
\hline DC & $513.7^{d}$ & 24.0 & 390.2 & $2993.9^{\mathrm{b}}$ & 7.7 \\
\hline DB & $548.9^{\mathrm{e}}$ & 17.9 & 450.5 & $2830.7^{b}$ & 6.3 \\
\hline
\end{tabular}

*The estimates were derived from those of Wang et al. [54].

$\mathrm{SR}=$ annual soil respiration, $\mathrm{HR}=$ annual heterotrophic respiration, $\mathrm{SOC}=$ soil organic carbon, $\mathrm{GR}=$ grassland, $\mathrm{SH}=$ shrubland, $\mathrm{EC}=$ evergreen coniferous forest, $\mathrm{DC}=$ deciduous coniferous forest, $\mathrm{DB}=$ deciduous broadleaved forest. Different lowercase letters in mean SR and SOC indicated significant differences $(P<0.05)$.

doi:10.1371/journal.pone.0071986.t004

To analyze the environmental differences among vegetation types, principal component analysis (PCA) was performed on correlations among ST, SWC, NDVI, SOC, STN, soil pH and $\mathrm{SBD}$, and the five vegetation types were ordered by their scores on the first two principal components. The relationships between annual SR and ST, SWC, NDVI, SOC, STN and live fine root biomass were examined by linear regression. The differences of SR among vegetation types were tested using one-way ANOVA. We used the averaged value of the five subsamples in each plot to
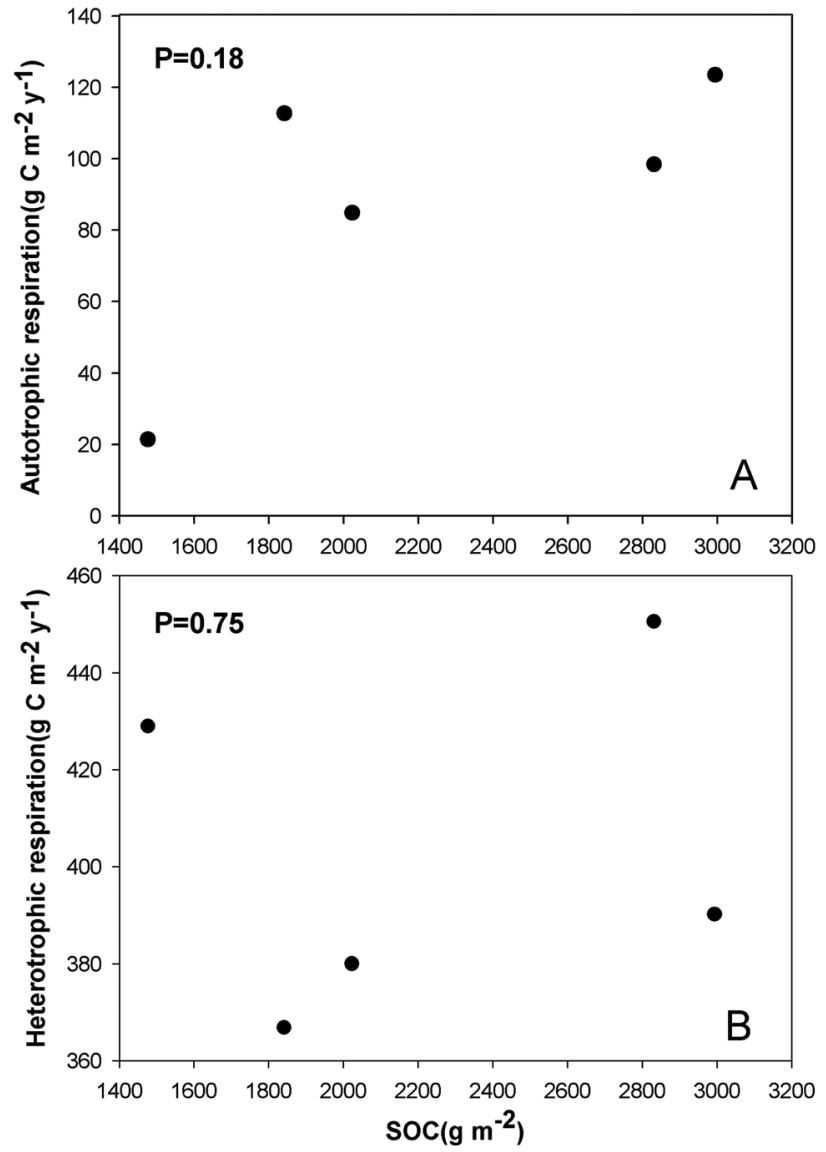

Figure 8. Relationships between heterotrophic respiration (A), autotrophic respiration (B) and soil organic carbon (SOC) across the five adjacent vegetation types.

doi:10.1371/journal.pone.0071986.g008 conduct statistical analysis. All statistical analyses were performed with a significance level of 0.05, using SPSS software (2009, ver. 18.0, SPSS Inc., Chicago, IL, USA).

\section{Results}

\section{Microenvironment of different vegetation types}

The annual average ST at $5 \mathrm{~cm}$ deep was not significantly different between grassland and woody vegetation types, with one exception (Table 1). The DB habitat had significantly lower ST at $5 \mathrm{~cm}$ deep and higher $\mathrm{SWC}$ at $10 \mathrm{~cm}$ deep. No significant differences in SWC occurred among GR, EC and DC habitats. The SH and DB habitats had lower soil bulk density than other vegetation types, but the DC forest and DB forest showed higher SOG content (Table $1, P<0.05)$. Furthermore, STN content was highest in DB forest, and its pattern was consistent with that of SWC across different vegetation types. There is no significant difference in soil $\mathrm{pH}$ among all vegetation types (Table 1).

PCA identified three significant principle components (eigenvalue $>1$ ) of variations (Fig. 3). The first two principle components explained $83 \%$ of the total variance in the dataset (Table 2, Table 3). The first principal component was mainly associated with the differences in ST, SWC, STN and soil pH across different vegetation types. The second and third principal components were correlated to SOC and NDVI, respectively. Among the four woody vegetation types, $\mathrm{EC}$ is the most similar environmentally to GR, followed by SH. However, DB and DG were the different from GR along the first and second principal component, respectively.

As expected, SR (Fig. 4) and ST (Fig. 5) were higher in summer and lower in winter (Fig. 4). The mean SR showed significant differences among five vegetation types, in the order of $\mathrm{GR}<\mathrm{EC}$ $<\mathrm{SH}<\mathrm{DC}<\mathrm{DB}$ (Fig. 4). The seasonal dynamics of SR were exponentially related to ST across different vegetation types, which explained $85 \%, 91 \%, 95 \%, 89 \%$ and $93 \%$ of the variation in SR for GR, SH, EC, DG and DB, respectively (Fig. 6).

Annual soil respiration and soil organic carbon turnover

Annual SR was lower in GR than in the woody vegetation types (Table 4). The annual SR increased by $3 \%$ following the conversion from GR to EC, $6 \%$ to $\mathrm{SH}, 14 \%$ to DC, and $22 \%$ to $\mathrm{DB}$. The variations in the annual $\mathrm{SR}$ among the five vegetation types were significantly correlated with SOC and STN, but not with ST, SWC, NDVI and fine root biomass (Fig. 7).

In contrast with the pattern of total SR, GR had higher annual heterotrophic respiration than $\mathrm{SH}, \mathrm{EC}$ and $\mathrm{DC}$, but lower than 
DB (Table 4). Because GR had a lower SOC content and higher heterotrophic respiration, the residence time of SOC in GR is shorter $(3.4 \mathrm{yr})$, in comparison with the relatively longer time in woody vegetation types $(5.0 \mathrm{yr}$ in $\mathrm{SH}, 5.3 \mathrm{yr}$ in $\mathrm{EC}, 6.3 \mathrm{yr}$ in DB and $7.7 \mathrm{yr}$ in DG, Table 4).

\section{Discussion}

\section{Effects of vegetation types on soil respiration}

Our estimates of annual SR ranged from 450.4 to $548.9 \mathrm{~g} \mathrm{C}$ $\mathrm{m}^{-2} \mathrm{yr}^{-1}$ (Table 4), which fell into the range reported in temperate areas $[55,56]$. Among the five vegetation types, GRs showed lower SR than woodlands, which contradicted with the conclusions made using a synthesis of global data that reported SR from various types of GRs was averaged about $20 \%$ greater than various types of forests [57]. Additionally, in a juniper woodlandgrassland pair in Kansas (USA), SR from GRs was 38\% higher than from woodlands [58]. Our findings therefore did not support earlier generalizations that state GRs tended to allocate large proportions of their photosynthate belowground, and this results in higher SR than occurs woodlands [58]. However, in a subalpine Australian ecosystem rates of respiration in woodland soils were twice more than those in nearby grassland soils, which is similar to our results [27].

Three factors, microclimate (ST and moisture), aboveground photosynthetic supply to roots and substrate availability have been known to be important controls on SR [57]. Our results suggested that SOC and STN were major contributing factors for the variations of $\mathrm{SR}$ among different vegetation types (Fig. 7). Heterotrophic respiration was the dominant component of total SR, ranging from $76 \%$ to $95 \%$ (Table 4 ). Therefore, we expected the correlation between SR and SOC was derived from the component of heterotrophic respiration, because heterotrophic respiration is a result of the mineralization of SOC that is stored in large stocks $[59,60,61]$ while autotrophic respiration depends on fresh photosynthates [62]. However, we did not observe a correlation between $\mathrm{HR}$ and SOC (Fig. 8A). Moreover, we observed an increasing trend of root respiration with an increase in SOC (Fig. 8B) although statistical test was not significant. Therefore, root respiration may be the main driver of the differences in SR between the different vegetation types. The correlation between root respiration and SOC may be attributable to the fact that higher root respiration is connected to higher photosynthetic activity $[63,64,65]$, which will increase the carbon input to soil and therefore SOG content. Therefore, accurate discrimination of root respiration and heterotrophic respiration from the total SR was critical for gaining an improved understanding of the driving factors of SR among different vegetation types. Our results thus indicate that when modeling SR across a temperate heterogeneous landscape, we should pay more attention to the differences in heterotrophic respiration and root respiration components among different vegetation types.

\section{Effects of vegetation types on soil carbon storage and turnover}

Reported changes of SOC storage varied widely with reported increases $[28,30,66]$, no change [58] and decreases [67,68,69]

\section{References}

1. Bond-Lamberty B, Thomson A (2010) Temperature-associated increases in the global soil respiration record. Nature 464: 579-582.

2. IPCC (2007) Climate Change 2007: The Physical Science Basis. Cambridge, UK: Contributions of Working Group I to the 4th Assessment Report of the Intergovernmental Panel on Climate Change. after grasslands were converted to woodlands. Our results showed that SOC storage was $92 \%$ higher in DB and 103\% higher in DC compared with GR (Table 4), suggesting possible larger amounts of organic carbon are input to soil through litterfall and root turnover in woodlands than grassland. Moreover, grasslands have been reported to have stronger wind erosion than woodlands in our study area, which reduced the soil clay and silt content, possibly explaining the potential reductions of surface organic matter in our study area [70,71]. However, no significant increase was observed when EC and SH (Table 4) were compared with GR, possibly because of the small sample size and large spatial heterogeneity seen in SOC in this study.

In our study area, mean residence time of the near-surface SOC pool in woody communities exceeded that of GR (Table 4). Similarly, McCulley et al. [66] also observed that both SR and mean residence time of the near-surface SOC pool in wooded communities (11 years) exceeded that of GRs (6 years) in a subtropical ecosystem. However, in paired juniper woodland and $\mathrm{C}_{4}$-dominated grassland sites, longer woodland topsoil residence time (33 years) was observed than in GRs (18 years) [58]. In addition, our estimates of SOC residence time were shorter than those of McCulley et al. [66] and Smith \& Johnson [58], partly because of the differences in the estimates of heterotrophic respiration. In our study, heterotrophic respiration comprised a large portion of total SR ( $76 \%$ to $95 \%$, Table 4$)$, whereas, Smith \& Johnson [58] assumed root respiration is $50 \%$ of SR and McCulley et al. [66] used three scenarios in which they assumed root respiration comprised $30 \%, 50 \%$, or $70 \%$ of total SR.

\section{Conclusion}

In conclusion, by determining SR and SOC dynamics in five adjacent vegetation types (GR, SH, EC, DC and DB) in the temperate area of northern China, we identified an increase in both annual SR and residence time of SOC from grassland to woody vegetation types. The increase in annual SR was coupled with changes in soil substrate availability (SOC and STN). The increases in SR suggest an increase in landscape-scale carbon emissions occurred during both natural and anthropogenic transitions occurred from grassland to plant communities dominated by woody vegetation. However, the SOC pool storage and its residence time also increased, suggesting a larger increase in carbon input than in carbon loss from the surface soil layer, thus implying an accumulation of SOC during grassland conversion into woodlands in temperate China.

\section{Acknowledgments}

We thanked two anonymous reviewers for their very constructive and valuable comments for its early version of our manuscript.

\section{Author Contributions}

Conceived and designed the experiments: WW. Performed the experiments: WW. Analyzed the data: WW WC WZ. Contributed reagents/ materials/analysis tools: HZ JF. Wrote the paper: WW WZ WC.

3. Bahn M, Rodeghiero M, Anderson-Dunn M, Dore S, Gimeno G, et al. (2008) Soil respiration in European grasslands in relation to climate and assimilate supply. Ecosystems 11: 1352-1367.

4. Bond-Lamberty B, Bunn AG, Thomson AM (2012) Multi-year lags between forest browning and soil respiration at high northern latitudes. PloS one 7: e50441. 
5. Davidson EA, Janssens IA (2006) Temperature sensitivity of soil carbon decomposition and feedbacks to climate change. Nature 440: 165-173.

6. Piao SL, FangJY, Ciais P, Peylin P, Huang Y, et al. (2009) The carbon balance of terrestrial ecosystems in China. Nature 458: 1009-1013.

7. Houghton RA (2010) How well do we know the flux of $\mathrm{CO}_{2}$ from land-use change? Tellus Series B-Chemical and Physical Meteorology 62: 337-351.

8. Creamer CA, Filley TR, Boutton TW, Oleynik S, Kantola IB (2011) Controls on soil carbon accumulation during woody plant encroachment: evidence from physical fractionation, soil respiration, and delta $\mathrm{C}-13$ of respired $\mathrm{CO}_{2}$. Soil Biology \& Biochemistry 43: 1678-1687.

9. Eclesia RP, Jobbagy EG, Jackson RB, Biganzoli F, Pineiro G (2012) Shifts in soil organic carbon for plantation and pasture establishment in native forests and grasslands of South America. Global Change Biology 18: 3237-3251.

10. Eldridge DJ, Bowker MA, Maestre FT, Roger E, Reynolds JF, et al. (2011) Impacts of shrub encroachment on ecosystem structure and functioning: towards a global synthesis. Ecology Letters 14: 709-722.

11. Livesley SJ, Kiese R, Miehle P, Weston CJ, Butterbach-Bahl K, et al. (2009) Soil-atmosphere exchange of greenhouse gases in a Eucalyptus marginata woodland, a clover-grass pasture, and Pinus radiata and Eucalyptus globulus plantations. Global Change Biology 15: 425-440.

12. Wheeler CW, Archer SR, Asner GP, McMurtry CR (2007) Climatic/edaphic controls on soil carbon/nitrogen response to shrub encroachment in desert grassland. Ecological Applications 17: 1911-1928.

13. Don A, Schumacher J, Freibauer A (2011) Impact of tropical land-use change on soil organic carbon stocks - a meta-analysis. Global Change Biology 17: 16581670 .

14. Dutra Aguiar AP, Ometto JP, Nobre C, Lapola DM, Almeida C, et al. (2012) Modeling the spatial and temporal heterogeneity of deforestation-driven carbon emissions: the INPE-EM framework applied to the Brazilian Amazon. Global Change Biology 18: 3346-3366.

15. Saner P, Loh YY, Ong RC, Hector A (2012) Carbon stocks and fluxes in tropical lowland dipterocarp rainforests in Sabah, Malaysian Borneo. PloS one 7: e29642.

16. Throop HL, Archer SR (2008) Shrub (Prosopis velutina) encroachment in a semidesert grassland: spatial-temporal changes in soil organic carbon and nitrogen pools. Global Change Biology 14: 2420-2431.

17. van der Werf GR, Morton DC, DeFries RS, Olivier JGJ, Kasibhatla PS, et al. (2009) $\mathrm{CO}_{2}$ emissions from forest loss. Nature Geoscience 2: 829-829.

18. Paul KI, Polglase PJ, Nyakuengama JG, Khanna PK (2002) Change in soil carbon following afforestation. Forest Ecology and Management 168: 241-257.

19. Perez-Quezada JF, Bown HE, Fuentes JP, Alfaro FA, Franck N (2012) Effects of afforestation on soil respiration in an arid shrubland in Chile. Journal of Arid Environments 83: 45-53.

20. Poeplau C, Don A (2013) Sensitivity of soil organic carbon stocks and fractions to different land-use changes across Europe. Geoderma 192: 189-201.

21. Wiesmeier M, Sporlein P, Geuss U, Hangen E, Haug S, et al. (2012) Soil organic carbon stocks in southeast Germany (Bavaria) as affected by land use, soil type and sampling depth. Global Change Biology 18: 2233-2245.

22. Lai LM, Zhao XC, Jiang LH, Wang YJ, Luo LG, et al. (2012) Soil respiration in different agricultural and natural ecosystems in an arid region. PloS one 7: e48011.

23. Arora VK, Boer GJ (2010) Uncertainties in the 20th century carbon budget associated with land use change. Global Change Biology 16: 3327-3348.

24. Browning DM, Archer SR, Asner GP, McClaran MP, Wessman CA (2008) Woody plants in grasslands: post-encroachment stand dynamics. Ecological Applications 18: 928-944.

25. Carbone MS, Winston GC, Trumbore SE (2008) Soil respiration in perennial grass and shrub ecosystems: linking environmental controls with plant and microbial sources on seasonal and diel timescales. Journal of Geophysical Research-Biogeosciences 113: G02022.

26. Gimeno TE, Escudero A, Delgado A, Valladares F (2012) Previous land use alters the effect of climate change and facilitation on expanding woodlands of Spanish Juniper. Ecosystems 15: 564-579.

27. Jenkins M, Adams MA (2010) Vegetation type determines heterotrophic respiration in subalpine Australian ecosystems. Global Change Biology 16: 209-219.

28. Boutton TW, Liao JD, Filley TR, Archer SR (2009) Belowground carbon storage and dynamics accompanying woody plant encroachment in a subtropical savanna. In: Lal R, Follett R, editors. Soil Carbon Sequestration and the Greenhouse Effect: Soil Science Society of America, Madison, WI. 181205.

29. Marin-Spiotta E, Sharma S (2013) Carbon storage in successional and plantation forest soils: a tropical analysis. Global Ecology and Biogeography 22: $105-117$

30. McKinley DC, Blair JM (2008) Woody plant encroachment by Juniperus virginiana in a mesic native grassland promotes rapid carbon and nitrogen accrual. Ecosystems 11: 454-468.

31. Barger NN, Archer SR, Campbell JL, Huang CY, Morton JA, et al. (2011) Woody plant proliferation in North American drylands: a synthesis of impacts on ecosystem carbon balance. Journal of Geophysical Research-Biogeosciences 116 : G00K07.

32. Houghton RA, Hackler JL (2003) Sources and sinks of carbon from land-use change in China. Global Biogeochemical Cycles doi:10.1029/2002GB001970.
33. Schimel DS, House JI, Hibbard KA, Bousquet P, Ciais P, et al. (2001) Recent patterns and mechanisms of carbon exchange by terrestrial ecosystems. Nature 414: 169-172.

34. Smith P, Davies CA, Ogle S, Zanchi G, Bellarby J, et al. (2012) Towards an integrated global framework to assess the impacts of land use and management change on soil carbon: current capability and future vision. Global Change Biology 18: 2089-2101.

35. Iqbal J, Hu R, Du L, Lan L, Shan L, et al. (2008) Differences in soil $\mathrm{CO}_{2}$ flux between different land use types in mid-subtropical China. Soil Biology \& Biochemistry 40: 2324-2333.

36. Li HM, Ma YX, Aide TM, Liu WJ (2008) Past, present and future land-use in Xishuangbanna, China and the implications for carbon dynamics. Forest Ecology and Management 255: 16-24.

37. Liu F, Wu XB, Bai E, Boutton TW, Archer SR (2011) Quantifying soil organic carbon in complex landscapes: an example of grassland undergoing encroachment of woody plants. Global Change Biology 17: 1119-1129.

38. Liu H, Zhao P, Lu P, Wang YS, Lin YB, et al. (2008) Greenhouse gas fluxes from soils of different land-use types in a hilly area of South China. Agriculture Ecosystems \& Environment 124: 125-135.

39. Sheng H, Yang YS, Yang ZJ, Chen GS, Xie JS, et al. (2010) The dynamic response of soil respiration to land-use changes in subtropical China. Global Change Biology 16: 1107-1121.

40. Tang XL, Liu SG, Zhou GY, Zhang DQ, Zhou CY (2006) Soil-atmospheric exchange of $\mathrm{CO}_{2}, \mathrm{CH}_{4}$, and $\mathrm{N}_{2} \mathrm{O}$ in three subtropical forest ecosystems in southern China. Global Change Biology 12: 546-560.

41. Berthrong ST, Jobbagy EG, Jackson RB (2009) A global meta-analysis of soil exchangeable cations, $\mathrm{pH}$, carbon, and nitrogen with afforestation. Ecological Applications 19: 2228-2241.

42. Fang JY, Chen AP, Peng CH, Zhao SQ, Ci L (2001) Changes in forest biomass carbon storage in China between 1949 and 1998. Science 292: 2320-2322.

43. Henry HAL (2008) Climate change and soil freezing dynamics: historical trends and projected changes. Climatic Change 87: 421-434.

44. Zhang Y, Liu H (2010) How did climate drying reduce ecosystem carbon storage in the forest-steppe ecotone? A case study in Inner Mongolia, China. Journal of Plant Research 123: 543-549.

45. You L, Shen JG, Pei H (2002) Climatic changes in recent 50 years and forecast for the next 10 25 years in Inner Mongolia. Meteorology of Inner Mongolia 4: 14-18 (in Chinese).

46. Elberling B (2007) Annual soil $\mathrm{CO}_{2}$ effluxes in the High Arctic: the role of snow thickness and vegetation type. Soil Biology \& Biochemistry 39: 646-654.

47. Kurganova I, De Gerenyu VL, Rozanova L, Sapronov D, Myakshina T, et al. (2003) Annual and seasonal $\mathrm{CO}_{2}$ fluxes from Russian southern taiga soils. Tellus Series B-Chemical and Physical Meteorology 55: 338-344.

48. Kirschbaum MUF (2004) Soil respiration under prolonged soil warming: are rate reductions caused by acclimation or substrate loss? Global Change Biology 10: $1870-1877$.

49. Leifeld J, Kogel-Knabner I (2005) Soil organic matter fractions as early indicators for carbon stock changes under different land-use? Geoderma 124: $143-155$.

50. Gamon JA, Field CB, Goulden ML, Griffin KL, Hartley AE, et al. (1995) Relationships between NDVI, canopy structure, and photosynthesis in 3 Californian vegetation types. Ecological Applications 5: 28-41.

51. Ahrends HE, Etzold S, Kutsch WL, Stoeckli R, Bruegger R, et al. (2009) Tree phenology and carbon dioxide fluxes: use of digital photography at for processbased interpretation the ecosystem scale. Climate Research 39: 261-274.

52. Richardson AD, Braswell BH, Hollinger DY, Jenkins JP, Ollinger SV (2009) Near-surface remote sensing of spatial and temporal variation in canopy phenology. Ecological Applications 19: 1417-1428.

53. Jakubauskas ME, Legates DR, Kastens JH (2001) Harmonic analysis of timeseries AVHRR NDVI data. Photogrammetric Engineering and Remote Sensing 67: 461-470.

54. Wang W, Peng SS, Fang JY (2010) Root respiration and its relation to nutrient contents in soil and root and EVI among 8 ecosystems, northern China. Plant and Soil 333: 391-401.

55. Raich JW, Schlesinger WH (1992) The global carbon-dioxide flux in soil respiration and its relationship to vegetation and climate. Tellus Series BChemical and Physical Meteorology 44: 81-99.

56. Wang W, Chen WL, Wang SP (2010) Forest soil respiration and its heterotrophic and autotrophic components: global patterns and responses to temperature and precipitation. Soil Biology \& Biochemistry 42: 1236-1244.

57. Raich JW, Tufekcioglu A (2000) Vegetation and soil respiration: correlations and controls. Biogeochemistry 48: 71-90.

58. Smith DL, Johnson L (2004) Vegetation-mediated changes in microclimate reduce soil respiration as woodlands expand into grasslands. Ecology 85: 33483361.

59. Fang CM, Smith P, Moncrieff JB, Smith JU (2005) Similar response of labile and resistant soil organic matter pools to changes in temperature. Nature 433: 57-59.

60. Knorr W, Prentice IC, House JI, Holland EA (2005) Long-term sensitivity of soil carbon turnover to warming. Nature 433: 298-301.

61. Reichstein M, Falge E, Baldocchi D, Papale D, Aubinet M, et al. (2005) On the separation of net ecosystem exchange into assimilation and ecosystem respiration: review and improved algorithm. Global Change Biology 11: 1424-1439. 
62. Högberg P, Nordgren A, Buchmann N, Taylor AFS, Ekblad A, et al. (2001) Large-scale forest girdling shows that current photosynthesis drives soil respiration. Nature 411: 789-792.

63. Bahn M, Schmitt M, Siegwolf R, Richrer A, Brüggemann N (2009) Does photosynthesis affect grassland soil-respired $\mathrm{CO}_{2}$ and its carbon isotope composition on a diurnal timescale? New Phytologist 182: 451-460.

64. Högberg P, Singh B, Löfvenius MO, Nordgren A (2009) Partitioning of soil respiration into its autotrophic and heterotrophic components by means of treegirdling in old boreal spruce forest. Forest Ecology \& Management 257: 1764 1767.

65. Schindlbacher A, Zechmeister-Boltenstern S, Jandl R (2009) Carbon losses due to soil warming: Do autotrophic and heterotrophic soil respiration respond equally? Global Change Biology 15: 901-913.

66. McCulley RL, Archer SR, Boutton TW, Hons FM, Zuberer DA (2004) Soil respiration and nutrient cycling in wooded communities developing in grassland. Ecology 85: 2804-2817.
67. Gill RA, Burke IC (1999) Ecosystem consequences of plant life form changes at three sites in the semiarid United States. Oecologia 121: 551-563.

68. Jackson RB, Banner JL, Jobbagy EG, Pockman WT, Wall DH (2002) Ecosystem carbon loss with woody plant invasion of grasslands. Nature 418: 623-626.

69. Wei XR, Shao MG, Fu XL, Horton R, Li Y, et al. (2009) Distribution of soil organic $\mathrm{C}, \mathrm{N}$ and $\mathrm{P}$ in three adjacent land use patterns in the northern Loess Plateau, China. Biogeochemistry 96: 149-162.

70. Zhou RL, Li YQ, Zhao HL, Drake S (2008) Desertification effects on C and N content of sandy soils under grassland in Horqin, northern China. Geoderma 145: $370-375$.

71. Zhang YK, Liu HY (2010) How did climate drying reduce ecosystem carbon storage in the forest-steppe ecotone? A case study in Inner Mongolia, China. Journal of Plant Research 123: 543-549.

72. Hou XY (2001) Vegetation Atlas of China (1: 1,000,000). Beijing, China: Science Press. 